\title{
A humanized antibody for imaging immune checkpoint ligand PD-L1 expression in tumors
}

\author{
Samit Chatterjee ${ }^{1, *}$, Wojciech G. Lesniak ${ }^{1, *}$, Matthew Gabrielson ${ }^{1}$, Ala Lisok ${ }^{1}$, \\ Bryan Wharram ${ }^{1}$, Polina Sysa-Shah ${ }^{1}$, Babak Behnam Azad ${ }^{1}$, Martin G. Pomper ${ }^{1,2}$ \\ and Sridhar Nimmagadda ${ }^{1,2}$ \\ ${ }^{1}$ Russell H. Morgan Department of Radiology and Radiological Science, Johns Hopkins University, Baltimore, MD, USA \\ 2 Sidney Kimmel Comprehensive Cancer Center, Johns Hopkins University, Baltimore, MD, USA \\ * These authors have contributed equally to this work
}

Correspondence to: Sridhar Nimmagadda, email: snimmagl@jhmi.edu

Keywords: MPDL3280A, immunotherapy, immune escape, molecular imaging, personalized medicine

Received: January 02, $2016 \quad$ Accepted: January 16, $2016 \quad$ Published: February 01, 2016

\section{ABSTRACT}

Antibodies targeting the PD-1/PD-L1 immune checkpoint lead to tumor regression and improved survival in several cancers. PD-L1 expression in tumors may be predictive of response to checkpoint blockade therapy. Because tissue samples might not always be available to guide therapy, we developed and evaluated a humanized antibody for non-invasive imaging of PD-L1 expression in tumors. Radiolabeled [ ${ }^{111}$ In]PD-L1-mAb and near-infrared dye conjugated NIR-PD-L1-mAb imaging agents were developed using the mouse and human cross-reactive PD-L1 antibody MPDL3280A. We tested specificity of [ ${ }^{111}$ In]PD-L1-mAb and NIR-PD-L1-mAb in cell lines and in tumors with varying levels of PD-L1 expression. We performed SPECT/CT imaging, biodistribution and blocking studies in NSG mice bearing tumors with constitutive PD-L1 expression (CHO-PDL1) and in controls (CHO). Results were confirmed in triple negative breast cancer (TNBC) (MDAMB231 and SUM149) and non-small cell lung cancer (NSCLC) (H2444 and H1155) xenografts with varying levels of PD-L1 expression. There was specific binding of [111 In]PD-L1-mAb and NIRPD-L1-mAb to tumor cells in vitro, correlating with PD-L1 expression levels. In mice bearing subcutaneous and orthotopic tumors, there was specific and persistent high accumulation of signal intensity in PD-L1 positive tumors (CHO-PDL1, MDAMB231, H2444) but not in controls. These results demonstrate that [ $\left.{ }^{111} \mathrm{In}\right]$ PD-L1-mAb and NIR-PD-L1-mAb can detect graded levels of PD-L1 expression in human tumor xenografts in vivo. As a humanized antibody, these findings suggest clinical translation of radiolabeled versions of MPDL3280A for imaging. Specificity of NIR-PD-L1-mAb indicates the potential for optical imaging of PD-L1 expression in tumors in relevant pre-clinical as well as clinical settings.

\section{INTRODUCTION}

Tumor cells avoid the immune response by exploiting immune checkpoints through expression of immunosuppressive molecules, recruitment of suppressive immune cell populations and secretion of soluble suppressive factors [1]. Immune checkpoints are inhibitory pathways integral to the immune system, which are critical for modulating the immune response to maintain self-tolerance and prevent autoimmunity. Most immune checkpoints involve ligand-receptor interactions, the inhibition of which repeal the immunosuppression exerted by tumor cells, leading to recognition and destruction of tumor cells by the immune system $[1,2]$. Treatment with antibodies blocking immune checkpoint pathway ligands and receptors has shown durable tumor regression and improved patient survival [1, 3-6]. Programmed death ligand-1 (PD-L1, B7-H1 or CD274) is emerging as a 
central player in immune checkpoint therapies.

PD-L1, a 290 amino acid type I transmembrane glycoprotein, is the primary ligand of programmed death-1 (PD-1). Binding of PD-L1 to PD-1 suppresses T-cell immune activity and restricts tumor cell killing $[1,7]$. PD-L1 expression is upregulated in the tumor microenvironment (TME), (possibly as an immuneevasion mechanism) [8] and may be due to: (i) increased PD-L1 expression on tumor cells by intrinsic oncogenic events (e.g., loss of phosphatase and tensin homolog) [9], (ii) tumor cell PD-L1 induction in response to T-cell secreted interferon-gamma [10] and (iii) PD-L1 expression on accumulated myeloid cells and/or dendritic cells that have suppressive effects on T-cells [11]. In cancer patients, there is a strong correlation between PD-L1 expression on tumor cells and poor prognosis [7]. Furthermore, in PD-1 and PD-L1 targeted therapies across multiple cancer types, there is a strong positive correlation between pre-treatment PD-L1 expression in TME and therapeutic response to PD-1/PD-L1 pathway inhibitions $[6,12,13]$.

Antibodies targeting PD-L1 (MPDL3280A, MEDI4736 and BMS-936559) have demonstrated antitumor activity in diverse tumor types, including renal cell carcinoma (RCC) [14], advanced melanoma [6], non-small cell lung cancer (NSCLC) $[6,14,15]$, and bladder cancer [13] among others [2, 16]. Nearly 45\% of patients with PD-L1 positive TME show an objective response (OR) following immune checkpoint blockade. Those observations suggest that expression of PD-L1 in tissue biopsies is a valuable biomarker for immune checkpoint therapies [2, 16, 17], but tissue samples are often impractical to obtain, particularly in the setting of recurrent and metastatic disease. Thus, non-invasive detection of the changes in PD-L1 expression in the TME may guide patient management.

MPDL3280A (Atezolizumab) is a humanized monoclonal IgG1k antibody with high affinity for both human and mouse PD-L1, with dissociation constants $\left(K_{\mathrm{d}}\right)$ of $0.43 \mathrm{nM}$ and $0.13 \mathrm{nM}$, respectively $[13,18]$. In clinical trials, MPDL3280A proved effective in several tumor types including NSCLC, RCC and TNBC $[6,13]$.

The clinical efficacy of MPDL3280A prompted us to investigate its application for non-invasive detection of PD-L1 expression in tumors. We developed radiolabeled and near-infrared (NIR) dye-tagged analogs of MPDL3280A (PD-L1-mAb) and tested their specificity in Chinese hamster ovary tumors with constitutive PDL1 expression. Observations from those studies were then validated in orthotopic and subcutaneous TNBC and NSCLC human tumor xenografts with varying levels of expression of PD-L1. Specific accumulation of SPECT and optical imaging signal intensity was seen in tumors with high PD-L1 expression. Specificity of the uptake was confirmed by ex vivo biodistribution and immunohistochemistry studies. Our results with a humanized PD-L1-mAb confirm PD-L1-specific signal accumulation in multiple tumor models. These studies demonstrate imaging of PD-L1 in vivo and provide the basis for clinical translation of derivatives of anti-PD-L1 antibodies for imaging.

\section{RESULTS}

\section{Radiolabeling}

Radiolabeled [ $\left.{ }^{111} \mathrm{In}\right] \mathrm{PD}-\mathrm{L} 1-\mathrm{mAb}$ was produced with a specific activity of $4.8 \pm 0.65 \mu \mathrm{Ci} / \mu \mathrm{g}$ with $>98 \%$ and $\sim 75 \%$ radiochemical purity and immunoreactive fraction, respectively (Supplementary Figure 1A-1C).

\section{PD-L1 antibody imaging probes show specificity in vitro}

We selected CHO-PDL1, CHO, MDAMB231, SUM149, H2444, and H1155 cells to analyze the specificity of PD-L1-mAb to detect graded levels of PD-L1 expression. The percentage of cells that were positive for cell surface PD-L1 expression varied markedly, as shown by flow cytometry: CHO-PDL1 (99\%), H2444 (95\%), MDAMB231 (27\%), SUM149 (0.1\%), H1155 (0\%) and $\mathrm{CHO}$ cells ( $0 \%)$. Furthermore, PD-L1 expression levels, as shown by mean fluorescence intensity (MFI), also varied between cell types. The graded expression profile was: CHO-PDL1 > H2444 > MDAMB231 > SUM149 > H1155 $>$ CHO (Figure 1A and 1B, Supplementary Figure 2). The uptake values, determined by incubation of [ $\left.{ }^{111} \mathrm{In}\right] \mathrm{PD}-\mathrm{L} 1-$ $\mathrm{mAb}$ with $10^{6}$ cells of each cell line, showed: CHO-PDL1 $>\mathrm{H} 2444>$ MDAMB231 > SUM149 > H1155 > CHO (Figure 1C).

Blocking of $\left[{ }^{111} \mathrm{In}\right] \mathrm{PD}-\mathrm{L} 1-\mathrm{mAb}$ binding to $\mathrm{CHO}-$ PDL1 cells, by addition of 10-fold molar equivalent excess of unlabeled antibody, reduced radioactivity uptake by $75 \%$, indicating that $\left[{ }^{111} \mathrm{In}\right] \mathrm{PD}-\mathrm{L} 1 \mathrm{mAb}$ binding is specific. A similar uptake profile was observed with NIR-PD-L1$\mathrm{mAb}$ (Figure 1D). These in vitro data indicate that PD-L1 targeted antibody-based imaging probes can be used to detect graded levels of PD-L1 expression in cancer cells.

\section{PD-L1 mAb shows specific uptake in tumors with stable PD-L1 expression}

Several factors, as discussed in the introduction, contribute to changes in PD-L1 expression in the tumor microenvironment. Accordingly, we first established the in vivo specificity of $\left[{ }^{111} \mathrm{In}\right] \mathrm{PD}-\mathrm{L} 1-\mathrm{mAb}$ in tumors with constitutive PD-L1 expression. SPECT/CT images acquired over $120 \mathrm{~h}$ demonstrated substantial and specific accumulation of [ [ $\left.{ }^{11} \mathrm{In}\right] \mathrm{PD}-\mathrm{L} 1-\mathrm{mAb}$ in CHO-PDL1 tumors but not in control CHO tumors (Figure 2A). Radioactivity 
accumulation could also be seen in the lungs, liver, and spleen.

To validate the imaging results and to establish protein dose requirements, a protein-dose escalation biodistribution study was performed. In mice injected with [111 In]PD-L1-mAb alone, at $48 \mathrm{~h}$, the highest uptake (in $\% \mathrm{ID} / \mathrm{g}$ ) was in spleen $(23.5 \pm 8.2)$, followed by CHO-PDL1 tumor (4.7 \pm 0.7$)$ and liver (8.2 \pm 4.5$)$ (Table 1). In contrast, in mice co-injected with 10,30 and $90 \mu \mathrm{g}$ of unlabeled antibody, the highest uptake was in CHO-PDL1 tumors, in which $\% \mathrm{ID} / \mathrm{g}$ was $13 \pm 412.5 \pm 0.6$, and $13.3 \pm 1.6$ for 10 , 30 and $90 \mu \mathrm{g}$ dose cohorts, respectively. In the spleen, uptake significantly decreased with increased antibody dose, suggesting that spleen acts as a sink for this specific antibody. There were no significant changes in other tissues, nor in tumor or tissue uptake between 30 and 90 $\mu \mathrm{g}$ dose cohorts. Based on the high CHO-PDL1 tumor-tomuscle (21.7 \pm 1.3$)$ and CHO-PDL1 tumor-to-blood ratios (2.5 \pm 0.1$)$, all other biodistribution studies were performed with $30 \mu \mathrm{g}$ co-injection of unlabeled antibody.

We further evaluated the temporal changes in [ $\left.{ }^{111} \mathrm{In}\right]$ PD-L1-mAb (30 $\mu \mathrm{g}$ dose) biodistribution in the CHOPDL1 tumor model at $120 \mathrm{~h}$ (Table 1). There was a substantial accumulation of radioactivity in CHO-PDL1 tumors $(16.5 \pm 3.0 \% \mathrm{ID} / \mathrm{g})$. Blood pool radioactivity was reduced and spleen uptake was increased at $120 \mathrm{~h}$. In all other tissues, there was no significant difference in $\% \mathrm{ID} / \mathrm{g}$ between 48 and $120 \mathrm{~h}$ time points. Thus for CHOPDL1 tumors, by $120 \mathrm{~h}$, there was high tumor-to-muscle (38.7 \pm 8.0$)$ and tumor-to-blood ratios (5.8 \pm 1.9$)$, accounting for the tumor-specific high image contrast seen in the SPECT/CT images.
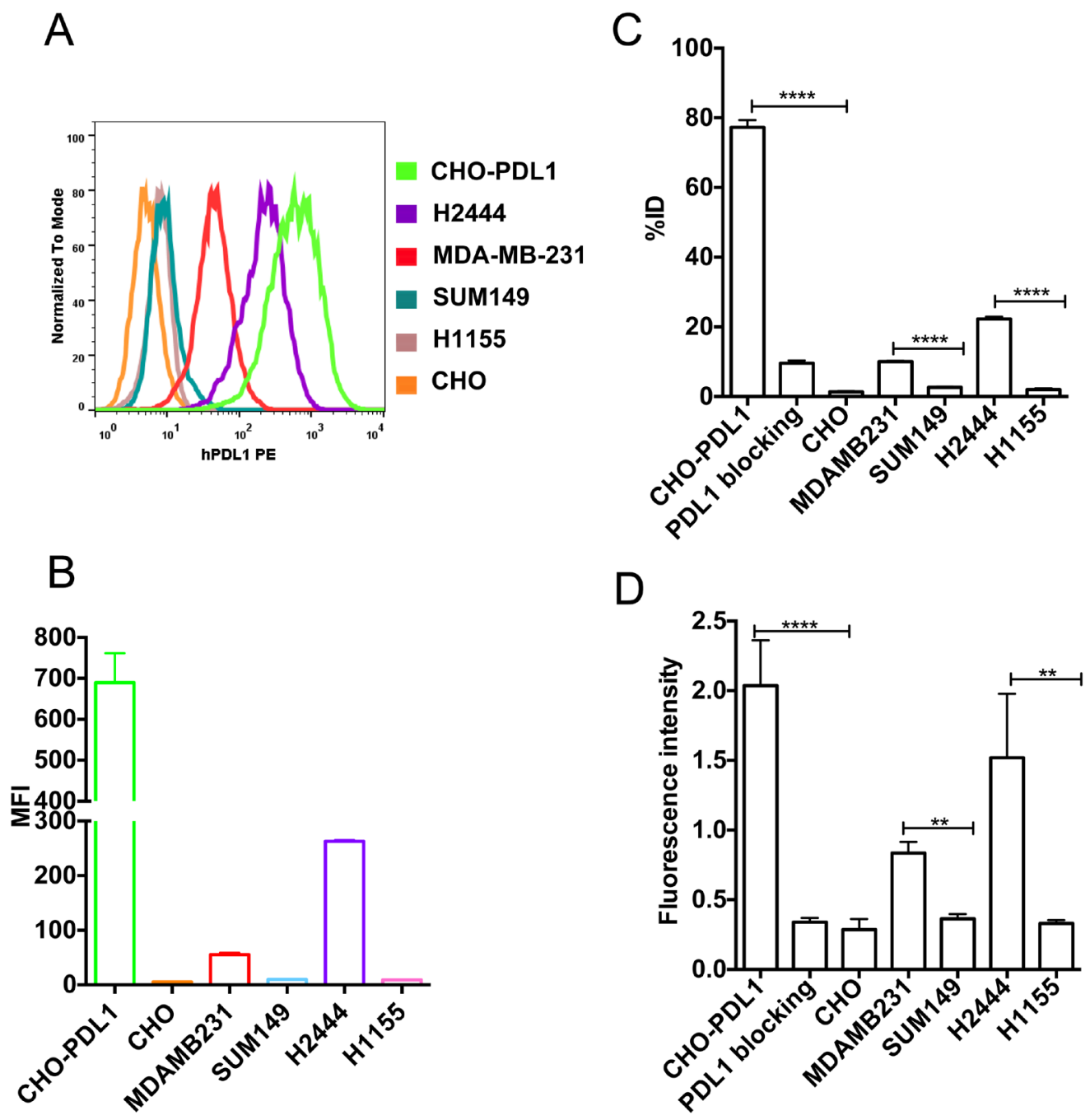

Figure 1: In vitro specificity of [111 In]PD-L1-mAb and NIR-PD-L1-mAb. Flow cytometry analysis of various cell lines for cell surface PD-L1 expression A. Representative mean fluorescence intensity (MFI) values for PE conjugated anti-human PD-L1 antibody binding to various cell lines B. In vitro uptake of [111In]PD-L1-mAb in CHO-PDL1, CHO, MDAMB231, SUM149, H2444 and H1155 cells incubated with $37 \mathrm{kBq}(1 \mu \mathrm{Ci}) / 100 \mu \mathrm{L}$ of $\left[{ }^{111} \mathrm{In}\right] \mathrm{PD}-\mathrm{L} 1-\mathrm{mAb}$ at $37^{\circ} \mathrm{C}$ for $1 \mathrm{~h} \mathrm{C}$. In vitro uptake of NIR-PD-L1-mAb in CHO-PDL1, CHO, MDAMB231, SUM149, H2444 and H1155 cells incubated with $1 \mu \mathrm{M}$ NIR-PD-L1-mAb at $37^{\circ} \mathrm{C}$ for $1 \mathrm{~h}$ D. Data are represented as percentage of incubated dose (\%ID) per million cells and represent mean values of three experiments \pm SEM. The significance of the value is indicated by asterisks $\left(^{*}\right)$ and the comparative reference is the control or low PD-L1 expression cell line. $*^{*} p<0.01, * * * * p<0.0001$. 
Table 1: Biodistribution of ${ }^{111}$ In-PD-L1-mAb in NSG mice with CHO-PDL1 and control CHO tumors

\begin{tabular}{|c|c|c|c|c|c|c|}
\hline \multirow{3}{*}{ Tissue } & \multicolumn{6}{|c|}{${ }^{111} \mathrm{In}-\mathrm{PD}-\mathrm{L} 1-\mathrm{mAb}[40 \mu \mathrm{Ci} / 8.3 \mu \mathrm{g}]$} \\
\hline & \multicolumn{5}{|c|}{$48 \mathrm{~h}$ pi } & \multirow{2}{*}{\begin{tabular}{|l}
$120 \mathrm{~h}$ pi \\
$30 \mu \mathrm{g}^{\mathrm{a}}$
\end{tabular}} \\
\hline & --- & $10 \mu \mathrm{g}^{\mathrm{a}}$ & $30 \mu \mathrm{g}^{\mathrm{a}}$ & $90 \mu \mathrm{g}^{\mathrm{a}}$ & $1.5 \mathrm{mg}^{\mathrm{a}}$ & \\
\hline Blood & $0.90 \pm 0.13$ & $4.46 \pm 0.65$ & $4.99 \pm 0.59$ & $6.95 \pm 0.79$ & $5.75 \pm 0.1$ & $2.93 \pm 0.42$ \\
\hline Heart & $2.34 \pm 1.76$ & $1.31 \pm 0.91$ & $1.64 \pm 0.07$ & $2.22 \pm 0.59$ & $1.92 \pm 0.1$ & $1.31 \pm 0.18$ \\
\hline Lungs & $5.95 \pm 0.72$ & $3.55 \pm 0.63$ & $3.12 \pm 0.29$ & $3.99 \pm 1.07$ & $3.23 \pm 0.01$ & $4.09 \pm 0.48$ \\
\hline Liver & $8.24 \pm 4.52$ & $5.03 \pm 0.13$ & $3.62 \pm 0.51$ & $3.5 \pm 0.40$ & $4.66 \pm 0.21$ & $5.07 \pm 0.4$ \\
\hline Stomach & $2.86 \pm 0.71$ & $1.09 \pm 0.20$ & $1.13 \pm 0.18$ & $1.12 \pm 0.19$ & $0.99 \pm 0.08$ & $1.44 \pm 0.11$ \\
\hline Pancreas & $1.96 \pm 0.41$ & $0.73 \pm 0.11$ & $0.72 \pm 0.09$ & $0.72 \pm 0.12$ & $0.72 \pm 0.05$ & $1.12 \pm 0.34$ \\
\hline Spleen & $23.55 \pm 8.2$ & $7.44 \pm 2.78$ & $4.75 \pm 0.38$ & $4.02 \pm 0.63$ & $21.2 \pm 6.05$ & $\begin{array}{l}18.23 \\
\pm 4.85 \\
\end{array}$ \\
\hline Kidney & $12.91 \pm 6.51$ & $2.64 \pm 0.19$ & $2.28 \pm 0.26$ & $2.39 \pm 0.31$ & $7.55 \pm 9.32$ & $4.09 \pm 1.58$ \\
\hline Small Int. & $11.81 \pm 1.55$ & $1.87 \pm 0.3$ & $1.22 \pm 0.25$ & $1.02 \pm 0.20$ & $0.87 \pm 0.01$ & $2.88 \pm 0.19$ \\
\hline Muscle & $0.61 \pm 0.06$ & $0.58 \pm 0.11$ & $0.58 \pm 0.06$ & $0.51 \pm 0.01$ & $0.61 \pm 0.06$ & $0.43 \pm 0.07$ \\
\hline Bladder & $2.08 \pm 0.37$ & $2.28 \pm 0.41$ & $1.71 \pm 1.25$ & $2.75 \pm 0.42$ & $2.67 \pm 0.13$ & $2.18 \pm 0.18$ \\
\hline Fat & $1.33 \pm 0.53$ & $2.61 \pm 1.53$ & $0.62 \pm 0.09$ & $0.65 \pm 0.28$ & $0.75 \pm 0.18$ & $0.86 \pm 0.40$ \\
\hline CHO-PDL1 & $4.68 \pm 0.69$ & $14.36 \pm 3.75^{b}$ & $12.51 \pm 0.99^{b}$ & $13.93 \pm 1.01^{b}$ & $5.91 \pm 0.35^{\mathrm{c}}$ & \begin{tabular}{|l|}
16.47 \\
$\pm 3.01^{\mathrm{b}}$ \\
\end{tabular} \\
\hline CHO & $3.44 \pm 0.59$ & $3.18 \pm 0.29$ & $2.68 \pm 0.27$ & $2.87 \pm 1.11$ & $3.05 \pm 1.03$ & $2.36 \pm 0.59$ \\
\hline $\begin{array}{l}\text { CHO-PDL1: } \\
\text { muscle }\end{array}$ & $5.37 \pm 0.95$ & $24.62 \pm 8.42$ & $21.71 \pm 1.28$ & $24.25 \pm 3.18$ & $9.75 \pm 0.98$ & \begin{tabular}{|l|}
38.22 \\
\pm 3.56 \\
\end{tabular} \\
\hline $\begin{array}{l}\text { CHO-PDL1: } \\
\text { blood }\end{array}$ & $5.22 \pm 0.27$ & $3.36 \pm 0.94$ & $2.51 \pm 0.11$ & $2.12 \pm 0.52$ & $1.03 \pm 0.05$ & $5.79 \pm 1.87$ \\
\hline $\begin{array}{l}\text { CHO: } \\
\text { Muscle } \\
\end{array}$ & $3.95 \pm 0.78$ & $4.98 \pm 1.61$ & $4.66 \pm 0.66$ & $4.77 \pm 0.77$ & $5.03 \pm 1.65$ & $5.45 \pm 0.86$ \\
\hline $\begin{array}{l}\text { CHO: } \\
\text { blood }\end{array}$ & $3.83 \pm 0.25$ & $0.67 \pm 0.15$ & $0.11 \pm 0.11$ & $0.41 \pm 0.06$ & $0.53 \pm 0.18$ & $0.83 \pm 0.32$ \\
\hline
\end{tabular}

pi - post injection; a - amount of unmodified mAb co-injected with radiotracer; $\mathrm{b}, p<0.0001$, comparative reference is $\mathrm{CHO}$ tumor; c, $p<0.001$, comparative reference is CHO-PDL1 tumor uptake with $30 \mu \mathrm{g}$ parent antibody dose.

In vivo $\mathrm{PD}-\mathrm{L} 1$ specificity of the antibody was further validated in mice that received $1.5 \mathrm{mg}$ of unlabeled PD$\mathrm{L} 1 \mathrm{mAb}$ as blocking dose, in which there was a $65 \%$ decrease $(P<0.001)$ in CHO-PDL1 tumor radioactivity uptake (Table 1). That tumor specific radioactivity uptake was corroborated by intense immunoreactivity observed in CHO-PDL1 tumors (Supplementary Figure 3).

Similarly, in NIR-PD-L1-mAb-injected mice, signal intensity was consistent and substantial in CHOPDL1 tumors during the $120 \mathrm{~h}$ study (Figure 2B). Biodistribution studies at $120 \mathrm{~h}$ showed a 3 -fold increase in fluorescence signal intensity in the CHO-PDL1 tumors compared to $\mathrm{CHO}$ control tumors $(P<0.0001$, Figure $2 \mathrm{C}$ and 2D). Liver, lungs, and kidneys also showed a distinct accumulation of fluorescence signal. These results show that NIR-PD-L1-mAb can be used to specifically detect tumor PD-L1 expression in vivo.

These data demonstrate: (i) $\left[{ }^{111} \mathrm{In}\right] \mathrm{PD}-\mathrm{L} 1-\mathrm{mAb}$ and NIR-PD-L1-mAb detect endogenous tumor PD-L1 expression, and (ii) in vivo specificity and dose dependent distribution of the anti-PD-L1 antibody.

\section{Increased uptake of PD-L1 mAb in TNBC xenografts with high PD-L1 expression}

SPECT/CT images of mice with MDAMB231 and SUM149 TNBC xenografts that were injected with [ $\left.{ }^{111} \mathrm{In}\right]$ PD-L1-mAb showed high radioactivity accumulation in the MDAMB231 tumors compared to SUM149 (Figure $3 \mathrm{~A})$. The distribution profile in other tissues was similar to that of the $\mathrm{CHO}$ tumor model. Biodistribution studies indicated highest radioactivity in MDAMB231, blood and spleen (Figure 3B). The $\% \mathrm{ID} / \mathrm{g}$ values for the MDAMB231 and SUM149 tumors were $8.9 \pm 0.26$ and $5.5 \pm 0.21$, respectively at $72 \mathrm{~h}$ after $\left[{ }^{111} \mathrm{In}\right] \mathrm{PD}-\mathrm{L} 1-\mathrm{mAb}$ injection. The tumor-to-muscle and tumor-to-blood ratios for MDAMB231 tumors at $120 \mathrm{~h}$ were $8.2 \pm 0.8$, and $0.79 \pm 0.06$, respectively. IHC evaluation showed strong PD-L1 immunoreactivity in MDAMB231 but not in SUM149 tumors (Figure 3C), validating $\left.{ }^{[11} \mathrm{In}\right] \mathrm{PD}-\mathrm{L} 1-$ $\mathrm{mAb}$ specificity.

Optical imaging of NIR-PD-L1-mAb distribution in the MDAMB231 and SUM149 xenografts during $120 \mathrm{~h}$ showed consistent and high fluorescence intensity in the MDAMB231 tumors compared to the SUM149 tumors 
(Figure 3D). Ex vivo analysis of the same mice confirmed the imaging observations (Figure $3 \mathrm{E}$ ). In addition to the MDAMB231 tumors, increased fluorescence intensity was observed in SUM149 tumors, liver and lungs (Figure
$3 \mathrm{E}$ and $3 \mathrm{~F})$. These studies establish that $\left[{ }^{111} \mathrm{In}\right] \mathrm{PD}-\mathrm{L} 1-$ $\mathrm{mAb}$ and NIR-PD-L1-mAb have the specificity to detect endogenous PD-L1 expression in TNBC tumors.

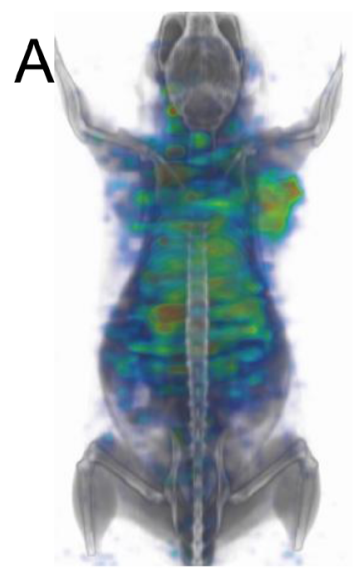

24h

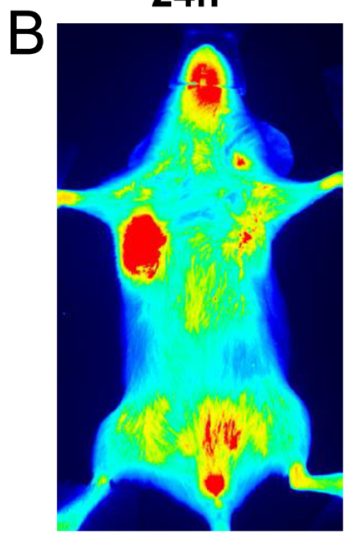

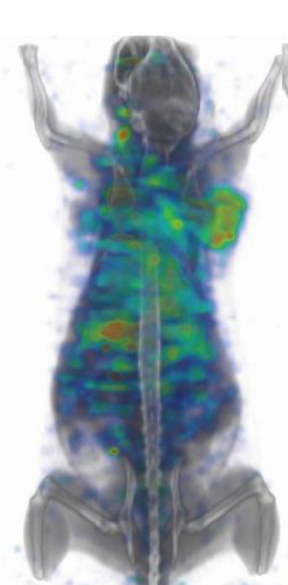

48h

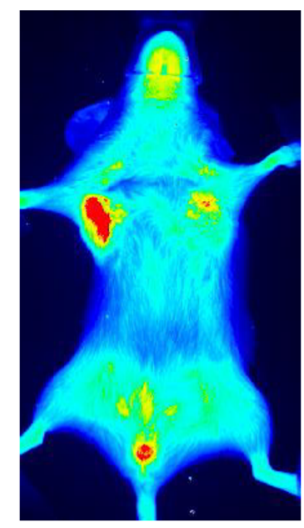

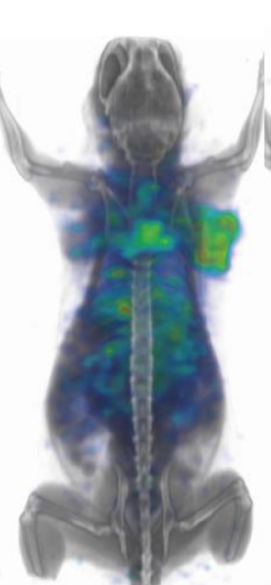

$72 \mathrm{~h}$

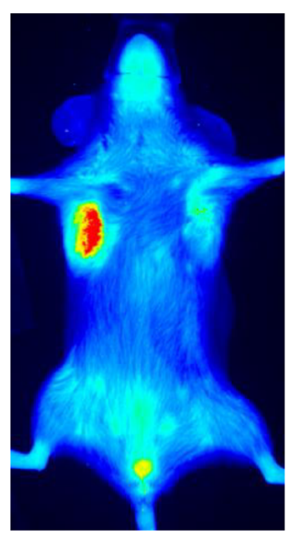

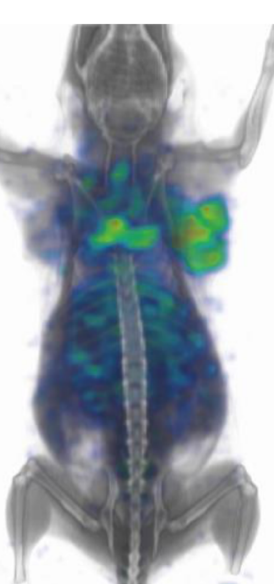

$96 \mathrm{~h}$

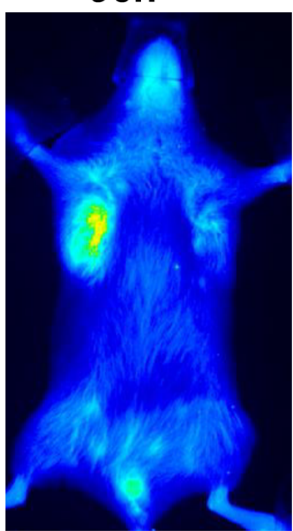

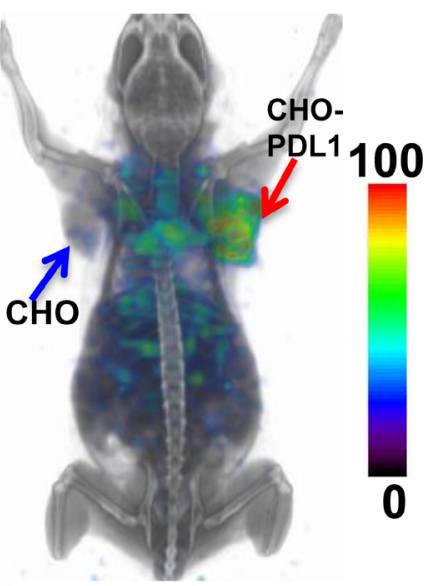

$120 \mathrm{~h}$

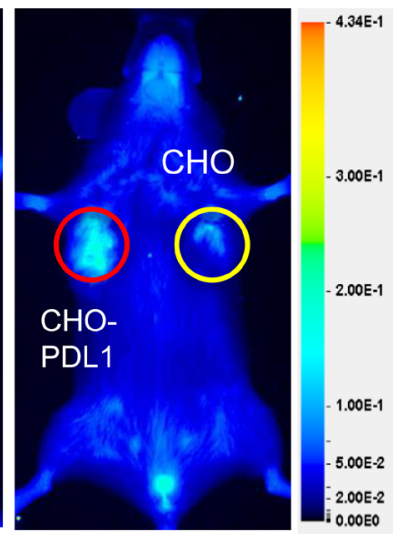

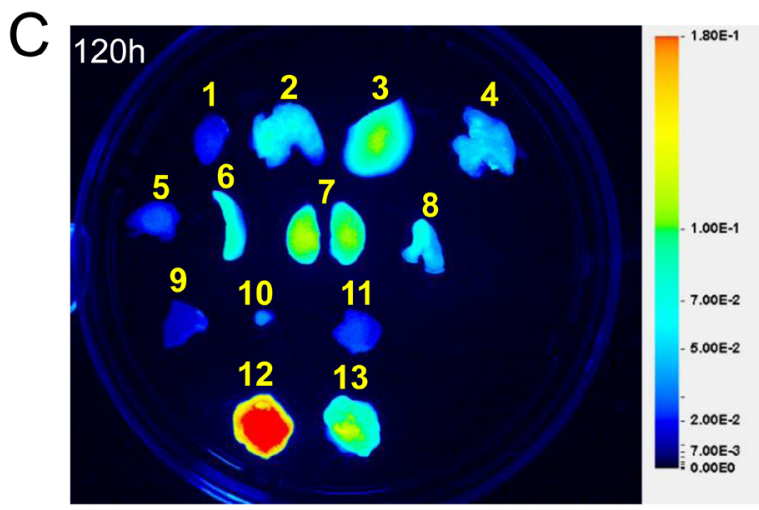

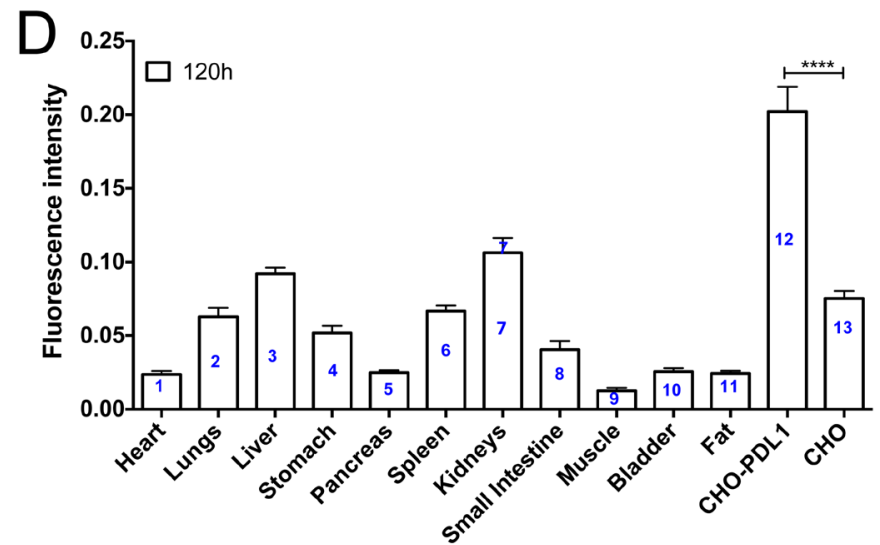

Figure 2: Imaging PD-L1 expression in subcutaneous CHO xenografts with [111In]PD-L1-mAb and NIR-PD-L1-mAb. NSG mice with CHO and CHO-PDL1 xenografts were administered intravenously with $14.8 \mathrm{MBq}(400 \mu \mathrm{Ci})$ of [ $\left.{ }^{111} \mathrm{In}\right] \mathrm{PD}-\mathrm{L} 1-\mathrm{mAb}$ or 22 $\mu \mathrm{g}$ of NIR-PD-L1-mAb and images were acquired at 24, 48, 72, 96 and $120 \mathrm{~h}$ after the injection of the mAbs. 3D volume rendered whole body SPECT/CT images demonstrate specific accumulation of activity in the CHO-PDL1 tumors A. Optical images acquired in the 800nm NIR channel B. Ex vivo biodistribution analysis representative image C. and semi-quantitative analysis of fluorescence intensity at 120 $\mathrm{h}$ after the injection of NIR-PD-L1-mAb $(n=5)$ D. Column numbers in panel D represent the tissue numbers in panel C. All the SPECT images were decay corrected and adjusted to the same maximum value to show the clearance of the imaging agent. The significance of the value is indicated by asterisk (*) and the comparative reference is the tumor with low PD-L1 expression. Arrows and circles depict tumors. $* * * * p<0.0001$. 


\section{Increased uptake of PD-L1 mAb in NSCLC xenografts with high PD-L1 expression}

SPECT/CT imaging of mice showed high accumulation of radioactivity in subcutaneous $\mathrm{H} 2444$ tumors by $120 \mathrm{~h}$, compared to H1155 tumors (Figure 4A), and the $\% \mathrm{ID} / \mathrm{g}$ for $\mathrm{H} 2444$ and $\mathrm{H} 1155$ tumors at 144 $\mathrm{h}$ were $7.46 \pm 0.12$ and $3.63 \pm 0.57$, respectively (Figure 4B). The tumor-to-muscle and tumor-to-blood ratios for
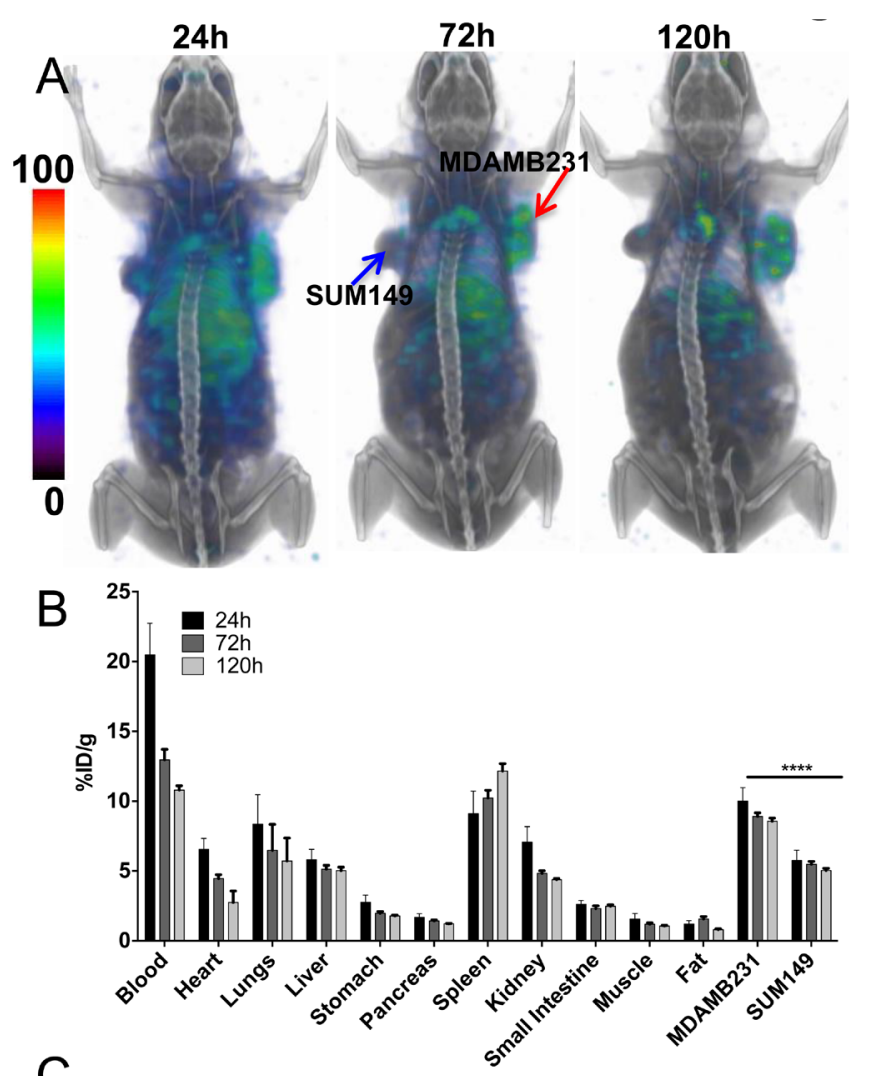

C
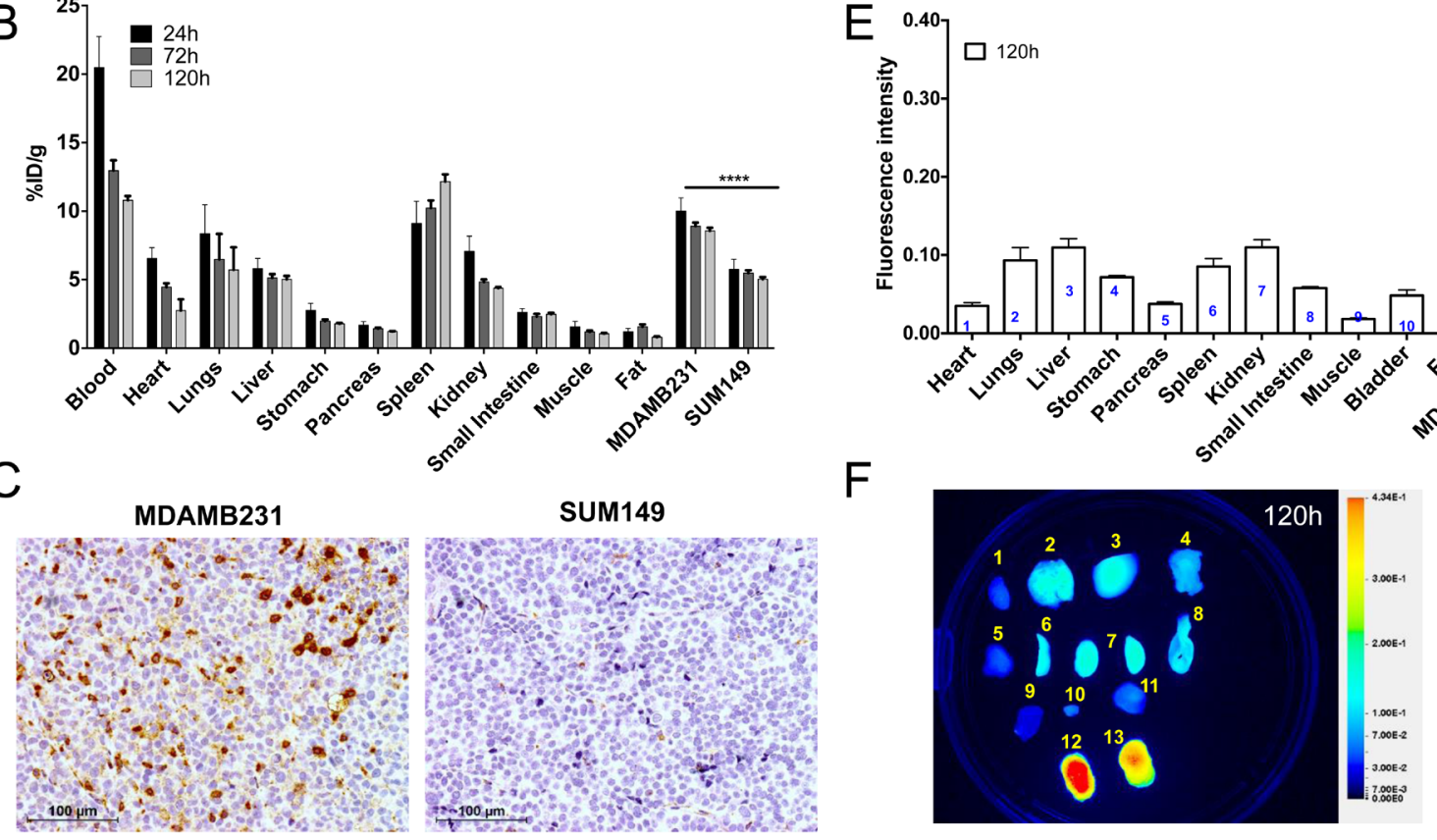

$\mathrm{H} 2444$ tumors were $8.9 \pm 0.8$ and $0.9 \pm 0.2$, respectively. IHC evaluation showed strong PD-L1 immunoreactivity in $\mathrm{H} 2444$ tumors but not in H1155 tumors (Figure $4 \mathrm{C})$, validating $\left[{ }^{111} \mathrm{In}\right] \mathrm{PD}-\mathrm{L} 1-\mathrm{mAb}$ specificity. In mice with orthotopic $\mathrm{H} 2444$ lung tumors, there was specific radioactivity accumulation delineating the tumors from normal lungs by $72 \mathrm{~h}$, and significant enhancement in contrast at $120 \mathrm{~h}$ (Figure 4D).

Optical imaging of H2444 and H1155 tumor bearing mice injected with NIR-PD-L1-mAb showed

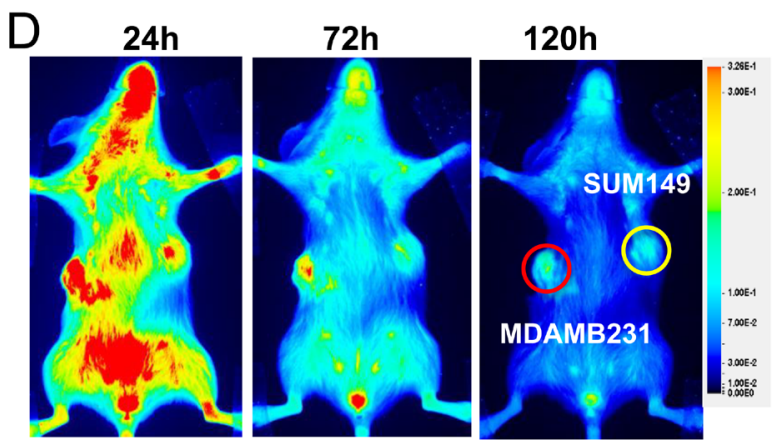

Figure 3: Imaging PD-L1 expression in orthotopic breast cancer xenografts with [ $\left.{ }^{111} \mathrm{In}\right]$ PD-L1-mAb and NIR-PDL1-mAb. NSG mice with orthotopic MDAMB231 and SUM149 xenografts were administered intravenously with $14.8 \mathrm{MBq}(400 \mu \mathrm{Ci})$ of [ $\left.{ }^{111} \mathrm{In}\right] \mathrm{PD}-\mathrm{L} 1-\mathrm{mAb}$ or $22 \mu \mathrm{g}$ of NIR-PD-L1-mAb and images were acquired at 24, 72, and $120 \mathrm{~h}$ after the injection of the mAbs. 3D volume rendered whole body SPECT/CT images demonstrating specific accumulation of activity in the MDAMB231 tumors A. Ex vivo biodistribution analysis of the ["11'In]PD-L1-mAb at $24 \mathrm{~h}, 72 \mathrm{~h}$ and $120 \mathrm{~h}$ after injection, in the same tumor models B.. Immunohistochemical analysis for PD-L1 expression demonstrating intense immunoreactivity in MDAMB231 tumors compared to SUM149 tumors C. Optical images acquired in the $800 \mathrm{~nm}$ NIR channel show specific accumulation of fluorescence signal in the MDAMB231 tumors D. Ex vivo biodistribution analysis of fluorescence intensity in tissues $(n=4) \mathbf{E}$. and representative image at $120 \mathrm{~h}$ after the injection of NIR-PD-L1mAb F. Column numbers in panel E represent the tissue numbers in panel F. SPECT images were decay corrected and adjusted to the same maximum value to show the clearance of the imaging agent.. The significance of the value is indicated by asterisk $\left(^{*}\right)$ and the comparative reference is the tumor with low PD-L1 expression. Arrows and circles depict tumors. ${ }^{*} p<0.05, * * * * p<0.0001$. 

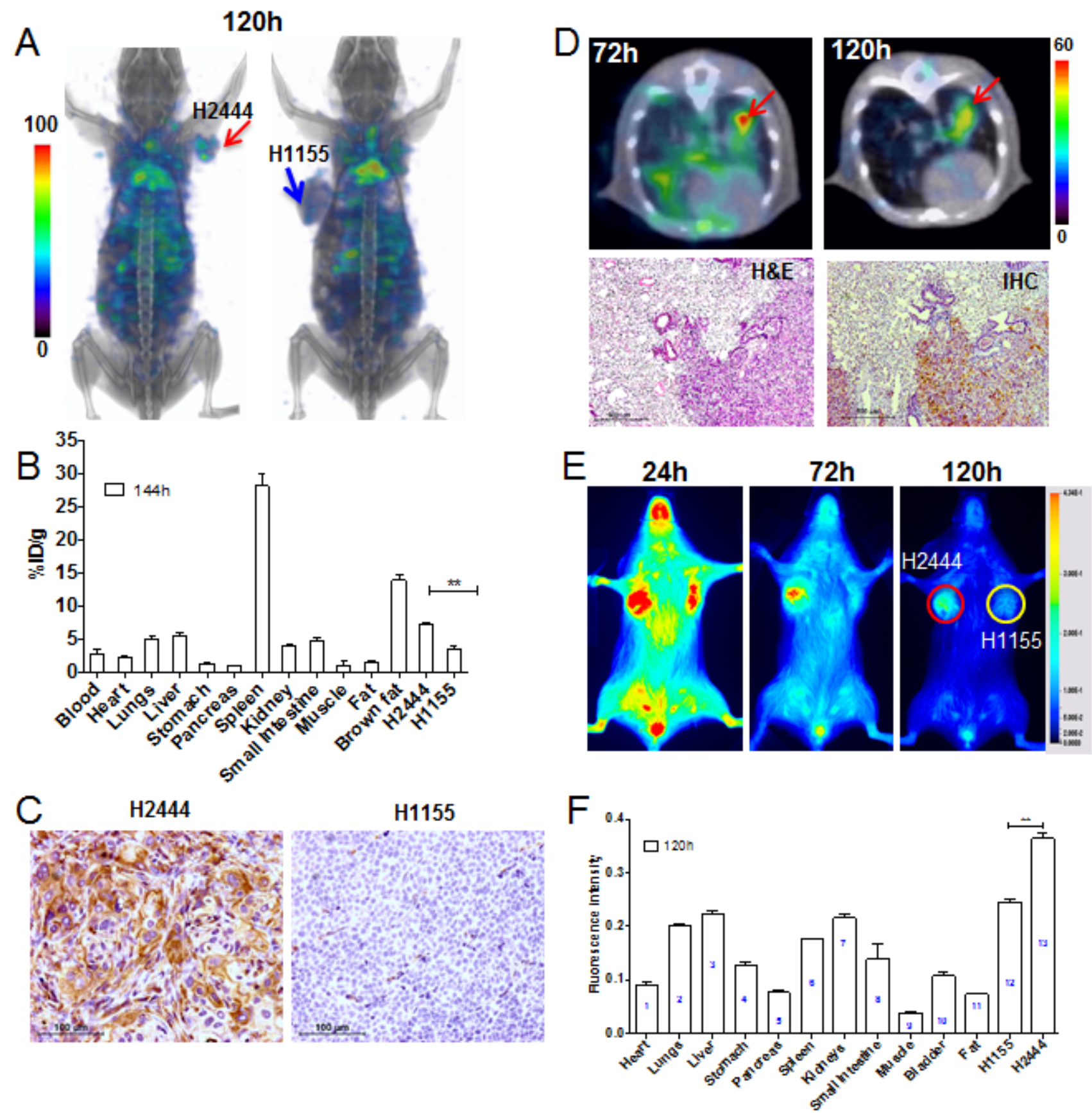

Figure 4: Imaging PD-L1 expression in subcutaneous and orthotopic lung cancer xenografts with [111n]PD-L1-mAb and NIR-PD-L1-mAb. NSG mice with subcutaneous H2444 or H1155 xenograft were administered intravenously with 14.8 MBq $(400 \mu \mathrm{Ci})$ of [ $\left.{ }^{111} \mathrm{In}\right] \mathrm{PD}-\mathrm{L} 1-\mathrm{mAb}$ or $22 \mu \mathrm{g}$ of NIR-PD-L1-mAb and images were acquired at the specified time after the injection of the mAbs. 3D volume rendered whole body images demonstrating specific accumulation of activity in the $\mathrm{H} 2444$ tumors at $120 \mathrm{~h}$ and not in the H1155 tumors A. Ex vivo biodistribution analysis of the [ $\left.{ }^{111} \mathrm{In}\right] \mathrm{PD}-\mathrm{L} 1-\mathrm{mAb}$, at $144 \mathrm{~h}$ after injection, in the same tumor models B. Immunohistochemical analysis for PD-L1 expression demonstrating intense immunoreactivity in H2444 tumors compared to H1155 tumors C. NSG mice with orthotopic H2444 xenografts were administered with $14.8 \mathrm{MBq}(400 \mu \mathrm{Ci})$ of [ $\left.{ }^{111} \mathrm{In}\right] \mathrm{PD}-\mathrm{L} 1-\mathrm{mAb}$ and SPECT/ CT images were acquired. Transaxial SPECT/CT images showing specific accumulation of activity in orthotopic H2444 xenograft at 72 $\mathrm{h}$ and $120 \mathrm{~h}$ after injection of the [ $\left.{ }^{111} \mathrm{In}\right] \mathrm{PD}-\mathrm{L} 1-\mathrm{mAb}$ and the corresponding histology D. Optical images of subcutaneous H2444 or H1155 xenograft acquired in the $800 \mathrm{~nm}$ NIR channel E. and ex vivo biodistribution analysis of fluorescence intensity in tissues $(n=3)$ F. SPECT images were decay corrected and adjusted to the same maximum value to show the clearance of the imaging agent. The significance of the value is indicated by asterisk $\left(^{*}\right)$ and the comparative reference is the tumor with low PD-L1 expression. Arrows and circles depict tumors. ${ }^{*} p<0.05 .{ }^{*} p<0.01$. 
specific accumulation of fluorescence intensity in H2444 tumors (Figure 4E). This was confirmed by ex vivo biodistribution analysis, which showed a nearly two-fold increase in signal intensity in the H2444 tumors compared to H1155 (Figure 4F and Supplementary Figure 4). High fluorescence intensity was also observed in liver and kidneys. Collectively, these studies establish the feasibility of imaging endogenous PD-L1 expression in NSCLC tumors.

\section{DISCUSSION}

Preclinical evaluation of a humanized radiolabeled anti-PD-L1 antibody, [ $\left.{ }^{111} \mathrm{In}\right] \mathrm{PD}-\mathrm{L} 1-\mathrm{mAb}$, shows specific and increased uptake of radioligand in $\mathrm{CHO}$ tumors with stable PD-L1 expression compared to control $\mathrm{CHO}$ tumors. The in vivo specificity of $\left[{ }^{111} \mathrm{In}\right] \mathrm{PD}-\mathrm{L} 1-\mathrm{mAb}$ was confirmed by differential uptake in human breast and lung tumor xenografts with endogenous high and low PD-L1 expression, and by studies with the fluorophore-conjugated antibody, NIR-PD-L1-mAb. The results demonstrate a new and non-invasive means to detect PD-L1 expression in tumors with an antibody ready for clinical translation.

We first characterized the distribution of $\left[{ }^{111} \mathrm{In}\right]$ PD-L1-mAb and protein dose effect on antibody biodistribution in $\mathrm{CHO}$ tumors with constitutive PDL1 expression [19]. Imaging and biodistribution studies showed that ${ }^{[11}$ In]PD-L1-mAb uptake in the tumors was PD-L1 specific and that overall tissue distribution and tumor uptake were concentration dependent. Co-injection of unlabeled antibody prolonged circulation of [ [ $\left.{ }^{111} \mathrm{In}\right] \mathrm{PD}$ L1-mAb, significantly increased the tumor uptake and reduced spleen uptake. These studies suggest that predosing with unlabeled antibody will improve tumor uptake of [ $\left.{ }^{111} \mathrm{In}\right] \mathrm{PD}-\mathrm{L} 1-\mathrm{mAb}$ and confirm reports from other PDL1 antibodies [19, 20]. This could be possible because high doses of PD-L1 antibody could saturate the PD-L1 expression in splenocytes, increasing availability of the radioactive antibody to bind target sites within tumor. The high tumor-to-muscle we observed at 72 and 120 $\mathrm{h}$, suggest that this would be the optimal time to image tumors with the $\left[{ }^{111} \mathrm{In}\right] \mathrm{PD}-\mathrm{L} 1-\mathrm{mAb}$.

We then tested the specificity of the $\left[{ }^{111} \mathrm{In}\right] \mathrm{PD}$ L1-mAb in TNBC xenografts with endogenous PD-L1 expression. TNBC has one of the poorest survival rates [21]. In patients with metastatic TNBC, MPDL3280A has shown promising clinical activity, providing a new therapeutic opportunity for a cancer subtype that heavily relies on chemotherapy [2]. Better understanding of the TNBC response to immunotherapy could be improved by PD-L1 imaging. Our studies with $\left[{ }^{111} \mathrm{In}\right] \mathrm{PD}-\mathrm{L} 1-\mathrm{mAb}$ demonstrated specific uptake in MDAMB231 tumors with high PD-L1 expression, compared to that in SUM149 tumors that have low PD-L1 expression, suggesting that non-invasive PD-L1 detection is a viable option for TNBC. Similar results were also observed in other studies [19]. The values we report for tumor $\% \mathrm{ID} / \mathrm{g}$ in the MDAMB231 tumors are lower than those recently reported by Heskamp et al. (2015) [19]. In addition, our flow cytometry analysis showed that approximately $30 \%$ of MDAMB231 cells were positive for PD-L1 expression, which was markedly lower than the $>90 \%$ of positive cells reported by Heskamp et al. [19], accounting for the differences in $\% \mathrm{ID} / \mathrm{g}$. Nevertheless, enhanced signal intensity accumulation and delineation of PD-L1 positive breast tumors is evident in our studies.

Immune checkpoint-targeted therapies have resulted in prolonged tumor regression and improved overall response rates, not only in immunogenic cancers such as melanoma and RCC, but also in cancers not believed to be immunogenic such as lung cancers. Treatment with MPDL3280A results in durable responses in NSCLC patients [6], and non-invasive PD-L1 detection in NSCLC may improve patient stratification. In an orthotopic lung tumor model (H2444), mice injected with [ $\left.{ }^{111} \mathrm{In}\right] \mathrm{PD}$ L1-mAb demonstrated SPECT signal in tumor regions that were spatially discrete from the normal lung, and aligned with tumor masses seen on CT by $72 \mathrm{~h}$. Similarly, subcutaneous NSCLC xenografts showed specific uptake in $\mathrm{H} 2444$ tumors compared to H1155 tumors. The $\% \mathrm{ID} / \mathrm{g}$ values for $\mathrm{H} 1155$ were similar to $\mathrm{CHO}$ and SUM149 xenografts with low PD-L1 expression levels. However, \% $\%$ D/g value for the H2444 tumor was found to be lower than what was anticipated based on the MFI values. Several factors can influence antibody uptake [22] and need to be investigated, including rapid tumor growth, enhanced permeability and retention, and tumor vascularity. Poor antibody delivery to the tumors could reduce therapeutic efficacy, despite their positive PD-L1 status. Non-invasive imaging, as we have demonstrated, could identify the disagreement between PD-L1 status and antibody delivery to the tumor. The clinical utility of such antibody imaging agents would be to use the radiolabeled antibody accumulation in the tumors to guide therapeutic antibody dosing and correlate that uptake with tumor response. This could be used to establish a relationship between tumor PD-L1 status and therapeutic response, which may have prognostic implications.

NIR intra-operative optical imaging has been used for staging and detection of tumor margins during cytoreductive surgery in ovarian cancer [23]. It is also becoming increasingly used to enhance tumor resection in brain surgery (using 5-aminolevulinic acid, scorpion venom, etc.) $[24,25]$, and new agents are emerging specific to a variety of other cancers, including prostate and breast [26-28]. With the NIR-PD-L1-mAb, PDL1 positive tumor contrast was high in PD-L1 positive CHO-PDL1, MDAMB231 and H2444 tumors compared to CHO, SUM149 and H1155 tumors. That specificity suggests that NIR-PD-L1-mAb could be used for noninvasive PD-L1 detection by optical imaging.

Molecular imaging based "optical biopsies" are used 
for identification of lung nodules in a shorter period of time than standard $\mathrm{IHC}$, and resection of those nodules with high success rates [29]. Similarly, NIR dye labeled EGFR antibody Cetuximab was used to visualize EGFR expression in head and neck squamous cell carcinomas [30]. NSCLCs show significant response rates for immune checkpoint targeted therapies and could benefit from availability of such technologies. Bronchoscopic imaging is routinely used for lung tumor diagnosis and staging but has not been used for PD-L1 expression status in lung tumors [31]. The specificity observed in the lung tumor models we tested indicates that NIR-PD-L1-mAb has the potential for bronchoscopic or thorascopic optical imaging of PD-L1 expression in lung tumors.

Imaging PD-L1 expression has recently been demonstrated using a mouse anti-human PD-L1 and hamster anti-mouse antibodies, and an engineered PD-1 derived fragment [19, 20, 32]. While those studies show the feasibility, the species from which the antibodies were derived and the near certainty of immunogenicity may curtail clinical translation, an experience observed with ProstaScint [33]. We chose MPDL3280A because it is in clinical trials and shows cross-reactivity to both human and mouse PD-L1 [13, 18]. Similarly crossreactive Cetuximab was used to image tumor EGFR expression in patients [34]. Demonstrating the power of cross-reactive antibodies to evaluate tumor biology, Cetuximab was also used to detect colon adenocarcinoma in the setting of colitis in immunocompetent mouse models [35]. Such cross-reactivity is more desirable in the case of PD-L1 imaging agents because of the need for immunocompetent model systems to evaluate the immune responses. Importantly, results from preclinical studies using those cross-reactive antibodies, such as the one we have demonstrated using MPDL3280A, may guide clinical studies.

A variety of normal tissues express PD-L1 transcripts, including placenta, lung, liver, spleen, lymph nodes and thymus [7]. [ $\left.{ }^{111} \mathrm{In}\right] \mathrm{PD}-\mathrm{L} 1-\mathrm{mAb}$ cross-reactivity is reflected in the high radioactivity uptake observed in mouse spleen, lungs and liver in our present study. This is similar to the observations made by Josefsson et al. using an anti-mouse PD-L1 antibody [20]. Antibody crossreactivity may also explain the significant differences in biodistribution reported in our study and the previous study using a mouse anti-human antibody by Heskamp et al. (2015) [19]. The consistently high radioactivity uptake observed in brown fat in our study, known to have immune cells, needs to be further investigated [36]. Because we used immunocompromised mouse models, the radioactivity uptake observed in immune related tissues could be less than one may see in immunocompetent mice. Nevertheless, our results provide an assessment of PD-L1 mAb distribution that could not be observed using either human-only or mouse-only reactive PD-L1 antibodies. Our data show human PD-L1 specific uptake of the antibody in the tumors, and mouse PD-L1 specific uptake in other tissues, and this provides a more detailed perspective on imaging PD-L1.

In summary, we have developed and evaluated nuclear and optical imaging agents for PD-L1 based on a humanized antibody. These represent two new tools that are ready for translation to patients undergoing immune checkpoint therapy. We have demonstrated PD-L1 specific accumulation of nuclear and fluorescent imaging agents in tumors with constitutive PD-L1 expression, and in TNBC and NSCLC xenografts with graded endogenous PD-L1 expression. The results demonstrate the feasibility of noninvasive PD-L1 imaging in vivo. PD-L1 has become an important target for cancer immunotherapy, and PD-L1targeted antibodies have proved effective $[6,13]$. Based on a humanized antibody that has shown therapeutic promise in patients, the presented data holds considerable potential for clinical translation. The patient management in advanced melanoma, breast and bladder cancers, in which PD-L1 antibodies have shown therapeutic efficacy but lack better response prediction and monitoring strategies, may particularly benefit from non-invasive PD-L1 detection at all the tumor sites.

\section{MATERIALS AND METHODS}

\section{Reagents}

The published sequence for anti-hPD-L1 monoclonal antibody (MPDL3280A, clone YW243.55. S70) was used to guide the synthesis, performed by Evitria (Zurich, Switzerland) [13, 18]. All chemicals were purchased from Sigma-Aldrich or Fisher Scientific unless otherwise specified. The IRDye ${ }^{\circledR} 800 \mathrm{CW}$ NHS ester, CHX-A"- DTPA and $\left[{ }^{111} \mathrm{In}\right] \mathrm{Cl}_{3}$ were purchased from LI-COR (catalog \# 929-70020; Lincoln, Nebraska), Macrocyclics Inc. (catalog \# B355; Dallas, TX, USA,) and Nordion (Vancouver, BC, Canada), respectively. All cell culture related reagents were purchased from Invitrogen, unless otherwise specified.

\section{Cell lines}

Four cell lines NCI-H2444 (NSCLC, PD-L1 ${ }^{\text {high }}$ ), NCI-H1155 (NSCLC, PD-L1 1 ${ }^{\text {low }}$ ), MDAMB231 (TNBC, PD-L1 1 high) and CHO-K1, (henceforth referred to as $\mathrm{H} 2444$, H1155, MDAMB231 and CHO respectively), were purchased from the American Type Culture Collection (ATCC) and passaged for fewer than 3 months after which new cultures were initiated from vials of frozen cells. The SUM149 (TNBC, PD-L $1^{\text {low }}$ ) cell line was kindly provided by Dr. Stephen P. Ethier, Medical University of South Carolina, and authenticated by STR profiling at the Johns Hopkins genetic resources facility. SUM149 cells were 
maintained in Ham's F-12 medium with 5\% FBS, 1\% $\mathrm{P} / \mathrm{S}$ and $5 \mu \mathrm{g} / \mathrm{mL}$ insulin, and $0.5 \mu \mathrm{g} / \mathrm{mL}$ hydrocortisone. All other cell lines were cultured in ATCC recommended media in an incubator at $37^{\circ} \mathrm{C}$ in an atmosphere containing $5 \% \mathrm{CO}_{2}$. The $\mathrm{CHO}-\mathrm{PDL} 1$ cell line generation and maintenance are described in Supplementary Methods.

\section{Flow cytometry}

Cells in suspension were harvested by centrifugation with adherent cells detached using enzyme-free, PBSbased cell dissociation buffer (Gibco). The harvested cells were washed twice with flow cytometry buffer (1xPBS with $2 \mathrm{mM}$ EDTA and $0.5 \% \mathrm{FBS}$ ). Cells were stained with anti-human PD-L1 antibody conjugated with phycoerythrin (PE) (catalog \#557924, Becton Dickinson) according to the manufacturer's protocol and were analyzed on a FACSCalibur flow cytometer (Becton Dickinson). At least 20,000 events were recorded and analyzed using FlowJo software (Tree Star).

\section{Animal models}

Animal studies were performed according to the protocols approved by the JHU Animal Care and Use Committee (ACUC). Six-to-eight weeks old, female, non-obese diabetic severe-combined immunodeficient gamma (NSG) mice were obtained from the JHU Immune Compromised Animal Core. Mice were implanted subcutaneously in the upper flanks with CHO-PDL1 $\left(10 \times 10^{6}\right)$, CHO $\left(10 \times 10^{6}\right)$, H2444 $\left(10 \times 10^{6}\right)$, or H1155 $\left(2 \times 10^{6}\right)$ cells and orthotopically in the upper mammary fat pads with MDAMB231 $\left(2 \times 10^{6}\right)$, and SUM149 $\left(2 \times 10^{6}\right)$ cells in $100 \mu \mathrm{L}$ of HBSS containing $50 \%$ matrigel (Corning). Mice were used for imaging or biodistribution experiments when the tumors reached a volume of 200$300 \mathrm{~mm}^{3}$.

Orthotopic mouse models of lung tumors were generated by injecting lung cancer cells into the left lung of NSG mice. A $1 \mathrm{~cm}$ skin incision was made on the left scapula of the anesthetized mouse and the thoracic muscles were separated to expose the costal layer. The H2444 cells, $\left(1 \times 10^{6}\right.$ in $30 \mu \mathrm{L}$ HBSS containing $50 \%$ matrigel), were injected directly though the intercostal space into the left lung, by using a $29 \mathrm{G}$ needle on a $0.5 \mathrm{~mL}$ syringe. Skin incisions were closed by sutures and antibiotics were applied topically. Growth of the orthotopic lung tumor was monitored by CT imaging.

\section{Preparation of radiolabeled antibody}

The PD-L1 mAb was reacted with N-[(R)-2Amino-3-(p-isothiocyanato-phenyl) propyl]-trans-(S,S)cyclohexane-1,2-diamine-N,N,N',N",N"-pentaacetic acid
(CHX-A"-DTPA, \#B355, Macrocyclics, Inc.) in $0.1 \mathrm{M}$ sodium bicarbonate buffer $(\mathrm{pH}=9.5)$ at 1:50 mAb:CHXA"-DTPA molar ratio, for $1 \mathrm{~h}$ at room temperature. Unconjugated CHX-A"-DTPA was removed using a Zeba $^{\mathrm{TM}}$ spin desalting column, pre-equilibrated with 0.1 M 2-(N-morpholino)ethanesulfonic acid (MES) buffer. The DTPA-conjugated mAb was further purified on an Amicon ultra-4 centrifugal filter with 10k Da MWCO (\# UFC801024, EMD Millipore, Billerica), using $0.1 \mathrm{M}$ ammonium acetate $(\mathrm{pH}$ 5.5). Conjugation of CHX-A"-DTPA to antibody was confirmed by matrix assisted laser desorption ionization mass spectrometry. Radiolabeling of mAb-DTPA with ${ }^{111}$ In was carried out in $0.3 \mathrm{M}$ ammonium acetate $(\mathrm{pH} 5.5)$ for $1 \mathrm{~h}$ at $37^{\circ} \mathrm{C}$, under metal free conditions. The resulting $\left[{ }^{111} \mathrm{In}\right] \mathrm{PD}-\mathrm{L} 1-$ $\mathrm{mAb}$ was incubated with ethylenediaminetetraacetic acid (EDTA) at a final concentration of $5 \mathrm{mM}$ for $5 \mathrm{~min}$ to chelate unbound ${ }^{111} \mathrm{In}^{3+}$, and further purified on a desalting column. Radiochemical purity was tested by instant thinlayer chromatography (ITLC) (catalog \# 61885, Pall Life Science) using citrate-phosphate-dextrose solution as a mobile phase (Supplementary Figure 1A-1C).

\section{Preparation of NIR dye conjugated antibody}

Synthesis of PD-L1 mAb conjugated with Licor800 dye (NIR-PD-L1-mAb) was performed according to manufacturer's protocol. Briefly, $3 \mathrm{mg}$ of $\mathrm{mAb}$ dissolved in $400 \mu \mathrm{L}$ of $1 \mathrm{xPBS}$ were mixed with $4 \mu \mathrm{L}$ of DMSO containing $0.09 \mathrm{mg}$ of IRDye ${ }^{\circledR} 800 \mathrm{CW}$ NHS ester. The reaction mixture was gently stirred for $2 \mathrm{~h}$ at room temperature, followed by purification using PBS preequilibrated $\mathrm{Zeba}^{\mathrm{TM}}$ spin desalting columns, 7K MWCO, $0.5 \mathrm{~mL}$ (\#89882, Thermo Fisher Scientific). Analysis of the NIR-PD-L1-mAb was carried out using a Nanodrop 2000 UV-vis spectrophotometer (Thermo Fisher Scientific), which indicated 1:2 mAb:IR800 molar ratio (Supplementary Figure 1D).

\section{In vitro binding assay and immunoreactive fraction (IF) determination}

In vitro binding of $\left[{ }^{111} \mathrm{In}\right] \mathrm{PD}-\mathrm{L} 1-\mathrm{mAb}$ to $\mathrm{CHO}-$ PDL1, CHO, MDAMB231, SUM149, H2444, and H1155 cells was determined by incubating $1 \mu \mathrm{Ci}$ of $\left[{ }^{111} \mathrm{In}\right] \mathrm{PD}-\mathrm{L} 1-$ $\mathrm{mAb}$ with $1 \times 10^{6}$ cells (in triplicate for each cell line) for $1 \mathrm{~h}$ at $37^{\circ} \mathrm{C}$. PD-L1 blocking was performed by adding a 10 -fold molar equivalent excess of the non-labeled $\mathrm{mAb}$. After incubation, cells were washed three times with cold PBS prior to counting on an automated gamma counter (1282 Compugamma CS, Pharmacia/LKBNuclear, Inc., Gaithersburg, MD).

To determine the immunoreactive fraction (IF), binding of $\left[{ }^{111} \mathrm{In}\right] \mathrm{PD}-\mathrm{L} 1-\mathrm{mAb}$ to $4,2,1,0.5$ and 0.25 million CHO-PDL1 cells was carried out as described 
above. IF was calculated using the Lindmo assay [37]. All in vitro studies were performed in triplicate and repeated three times.

\section{SPECT/CT imaging and analysis}

Whole-body SPECT-CT images were acquired on an X-SPECT small animal SPECT/CT system (Gamma Medica Ideas, Northridge, CA, USA) as described previously [38]. Briefly, after an intravenous injection of approximately $400 \mu \mathrm{Ci}$ of $\left[{ }^{111} \mathrm{In}\right] \mathrm{PD}-\mathrm{L} 1-\mathrm{mAb}(100 \mu \mathrm{g}$ of antibody, $n=3$ ), images were acquired at the specified time points in mice. The tomographic data were acquired in 64 projections over $360^{\circ}$, at $45 \mathrm{~s}$ per projection, using medium energy pinhole collimators. CT images were acquired in 512 projections to allow anatomic coregistration. Images were reconstructed using the ordered subsets-expectation maximization algorithm, and 3D volume rendered decay corrected images were generated using Amira 5.5.0 software (Visage Imaging Inc.).

\section{Ex vivo biodistribution}

Specific activity of [111 In]PD-L1-mAb was optimized for in vivo distribution and tumor uptake in mice harboring $\mathrm{CHO}-\mathrm{PDL} 1$ and $\mathrm{CHO}$ xenografts. Mice ( $n=3-5$ /group) were injected intravenously with $40 \mu \mathrm{Ci}$ of [ $\left.{ }^{111} \mathrm{In}\right] \mathrm{PD}-\mathrm{L} 1-\mathrm{mAb}$ alone (approximately $\sim 8.5 \mu \mathrm{g}$ of the protein), or in combination with 10,30, and $90 \mu \mathrm{g}$ of unmodified PD-L1-mAb. For the blocking study, mice were pre-injected with $1.5 \mathrm{mg}$ of unmodified $\mathrm{mAb} 30 \mathrm{~min}$ before injection of [ $\left.{ }^{111} \mathrm{In}\right] \mathrm{PD}-\mathrm{L} 1-\mathrm{mAb}$. Blood, tumors, and selected tissues were harvested, weighed and counted in an automated gamma counter (1282 Compugamma CS, Pharmacia/LKBNuclear, Inc.) at $48 \mathrm{~h}$ after the $\left[{ }^{111} \mathrm{In}\right] \mathrm{PD}-$ L1-mAb injection. Following this optimization, all other biodistribution studies were performed with $40 \mu \mathrm{Ci}\left[{ }^{111} \mathrm{In}\right.$ ] PD-L1 mAb combined with $30 \mu \mathrm{g}$ of unmodified mAb.

Biodistribution studies were also carried out to confirm the imaging study results in $\mathrm{CHO} / \mathrm{CHO}-\mathrm{PDL} 1$, SUM149/MDAMB231 and H1155/H2444 xenograft models with low or high expression of PD-L1 respectively, at various time points after $\left[{ }^{111} \mathrm{In}\right] \mathrm{PD}-\mathrm{L} 1-\mathrm{mAb}$ injection. The percentage of injected dose per gram of tissue $(\% \mathrm{ID} / \mathrm{g})$ values were calculated based on signal decay correction and normalization to external ${ }^{111}$ In standards, which were measured in triplicate. Biodistribution data shown is mean \pm the standard error of the mean (SEM).

\section{Optical imaging}

PD-L1 expression in different tumor models was assessed by optical imaging using NIR-PD-L1. The NIRPD-L1 $(22 \mu \mathrm{g})$ was injected into the tail vein of the mice $(n=3-5)$ bearing tumors with low and high expression of PD-L1. Mice were anaesthetized with isoflurane and serial images of the dorsal, left lateral, ventral and right lateral surfaces were captured using the Pearl Impulse Imager in white light and $800 \mathrm{~nm}$ channels (Software v2.0, LI-COR Biosciences) at 24, 48, 72, 96 and $120 \mathrm{~h}$ post injection. On day 5 after the injection of NIR-PDL1-mAb, mice were euthanized and tumors and selected tissues were dissected and imaged ex vivo. To quantify the signal, equal sized regions of interest (ROIs) were drawn on tumors and tissues and on an area outside the mouse and representative of background. Mean signal intensity in each ROI was normalized by subtracting the background signal, and used for statistical analysis. Data shown is mean fluorescence intensity values \pm SEM.

\section{Immunohistochemistry}

Tumor sections were evaluated for PD-L1 expression by immunohistochemistry (IHC). Harvested tumors were fixed in $10 \%$ neutral buffered formalin, embedded in paraffin, and $4 \mu \mathrm{m}$ thick sections were obtained on slides. After deparaffinizing with xylene and alcohol gradients, antigen retrieval was done using 10 mM citrate buffer, pH 6.0 (\#S1699, Dako target retrieval solution). Tumor sections were then treated with $3 \%$ $\mathrm{H}_{2} \mathrm{O}_{2}$ for 10 minutes, blocked with $5 \%$ goat serum for 1 $\mathrm{h}$, and then incubated with a primary anti-human PD-L1 antibody (\#13684, Cell Signaling) at 1:500 dilution at $4^{\circ} \mathrm{C}$ overnight. Subsequently, using Dako CSAII Biotinfree Tyramide Signal Amplification System kit, slides were incubated with secondary antibody, amplification reagent, and with anti-fluorecein-HRP. Finally, staining was carried out by adding DAB chromogen. Sections were counterstained with hematoxylin, followed by dehydration with alcohol gradients, xylene washes and mounted with a cover slip.

\section{Data analysis}

Statistical analysis of in vitro receptor binding assay data and ex vivo biodistribution data were performed with Graphpad Prism 6 software using an unpaired two-tailed $\mathrm{t}$ test. When $P<0.05$, the difference between the compared groups was considered to be statistically significant.

\section{ACKNOWLEDGMENTS}

Funding for this study was provided by JHU Career Catalyst Award (SN), and partly by NIH R01CA16631 (SN), and Jerome L. Greene Foundation (to Dr. Antony Rosen). Resources were provided by NIH P30 CA006973 and P50 CA103175. We would like to thank Drs. Edward Gabrielson, Markus Hildinger, Sangeeta Ray and Jessie Nedrow for helpful discussions. 


\section{CONFLICTS OF INTEREST}

None.

\section{Editorial note}

This paper has been accepted based in part on peerreview conducted by another journal and the authors' response and revisions as well as expedited peer-review in Oncotarget.

\section{REFERENCES}

1. Topalian SL, Drake CG and Pardoll DM. Immune checkpoint blockade: a common denominator approach to cancer therapy. Cancer Cell. 2015; 27:450-461.

2. Lipson EJ, Forde PM, Hammers HJ, Emens LA, Taube JM and Topalian SL. Antagonists of PD-1 and PD-L1 in Cancer Treatment. Semin Oncol. 2015; 42:587-600.

3. Homet Moreno B and Ribas A. Anti-programmed cell death protein-1/ligand-1 therapy in different cancers. Br J Cancer. 2015; 112:1421-1427.

4. Topalian SL, Sznol M, McDermott DF, Kluger HM, Carvajal RD, Sharfman WH, Brahmer JR, Lawrence DP, Atkins MB, Powderly JD, Leming PD, Lipson EJ, Puzanov I, Smith DC, Taube JM, Wigginton JM, et al. Survival, durable tumor remission, and long-term safety in patients with advanced melanoma receiving nivolumab. J Clin Oncol. 2014; 32:1020-1030.

5. Gettinger SN, Horn L, Gandhi L, Spigel DR, Antonia SJ, Rizvi NA, Powderly JD, Heist RS, Carvajal RD, Jackman DM, Sequist LV, Smith DC, Leming P, Carbone DP, Pinder-Schenck MC, Topalian SL, et al. Overall Survival and Long-Term Safety of Nivolumab (Anti-Programmed Death 1 Antibody, BMS-936558, ONO-4538) in Patients With Previously Treated Advanced Non-Small-Cell Lung Cancer. J Clin Oncol. 2015; 33:2004-2012.

6. Herbst RS, Soria JC, Kowanetz M, Fine GD, Hamid O, Gordon MS, Sosman JA, McDermott DF, Powderly JD, Gettinger SN, Kohrt HE, Horn L, Lawrence DP, Rost S, Leabman M, Xiao Y, et al. Predictive correlates of response to the anti-PD-L1 antibody MPDL3280A in cancer patients. Nature. 2014; 515:563-567.

7. Okazaki T and Honjo T. PD-1 and PD-1 ligands: from discovery to clinical application. Int Immunol. 2007; 19:813-824.

8. Dong H, Zhu G, Tamada K and Chen L. B7-H1, a third member of the B7 family, co-stimulates T-cell proliferation and interleukin-10 secretion. Nat Med. 1999; 5:1365-1369.

9. Parsa AT, Waldron JS, Panner A, Crane CA, Parney IF, Barry JJ, Cachola KE, Murray JC, Tihan T, Jensen MC, Mischel PS, Stokoe D and Pieper RO. Loss of tumor suppressor PTEN function increases B7-H1 expression and immunoresistance in glioma. Nat Med. 2007; 13:84-88.
10. Taube JM, Anders RA, Young GD, Xu H, Sharma R, McMiller TL, Chen S, Klein AP, Pardoll DM, Topalian SL and Chen L. Colocalization of inflammatory response with B7-h1 expression in human melanocytic lesions supports an adaptive resistance mechanism of immune escape. Sci Transl Med. 2012; 4:127ra137.

11. Curiel TJ, Wei S, Dong H, Alvarez X, Cheng P, Mottram P, Krzysiek R, Knutson KL, Daniel B, Zimmermann MC, David O, Burow M, Gordon A, Dhurandhar N, Myers L, Berggren R, et al. Blockade of B7-H1 improves myeloid dendritic cell-mediated antitumor immunity. Nat Med. 2003; 9:562-567.

12. Taube JM, Klein A, Brahmer JR, Xu H, Pan X, Kim JH, Chen L, Pardoll DM, Topalian SL and Anders RA. Association of PD-1, PD-1 ligands, and other features of the tumor immune microenvironment with response to antiPD-1 therapy. Clin Cancer Res. 2014; 20:5064-5074.

13. Powles T, Eder JP, Fine GD, Braiteh FS, Loriot Y, Cruz C, Bellmunt J, Burris HA, Petrylak DP, Teng SL, Shen X, Boyd Z, Hegde PS, Chen DS and Vogelzang NJ. MPDL3280A (anti-PD-L1) treatment leads to clinical activity in metastatic bladder cancer. Nature. 2014; 515:558-562.

14. Brahmer JR, Tykodi SS, Chow LQ, Hwu WJ, Topalian SL, Hwu P, Drake CG, Camacho LH, Kauh J, Odunsi K, Pitot HC, Hamid O, Bhatia S, Martins R, Eaton K, Chen S, et al. Safety and activity of anti-PD-L1 antibody in patients with advanced cancer. N Engl J Med. 2012; 366:2455-2465.

15. Rizvi N, Brahmer JR, Sai-Hong Ignatious o, NH S and Khleif S. (2015). Safety and clinical activity of MEDI4736, an anti-programmed cell death-ligand 1 (PD-L1) antibody, in patients with non-small cell lung cancer (NSCLC). 2015 ASCO Annual Meeting (Journal of Clinical Oncology,), pp. 8032.

16. Sunshine J and Taube JM. PD-1/PD-L1 inhibitors. Curr Opin Pharmacol. 2015; 23:32-38.

17. Teng MW, Ngiow SF, Ribas A and Smyth MJ. Classifying Cancers Based on T-cell Infiltration and PD-L1. Cancer Res. 2015; 75:2139-2145.

18. Irving B, Chiu H, Maecker H, Mariathasan S, Lehar SM, $\mathrm{Wu}$ Y and Cheung J. (2012). Anti-PD-L1 Antibodies, compositions and articles of manufacture. In: Office USP, ed. (USA: Genentech, Inc.,).

19. Heskamp S, Hobo W, Molkenboer-Kuenen JD, Olive D, Oyen WJ, Dolstra H and Boerman OC. Noninvasive Imaging of Tumor PD-L1 Expression Using Radiolabeled Anti-PD-L1 Antibodies. Cancer Res. 2015; 75:2928-2936.

20. Josefsson A, Nedrow JR, Park S, Ray Banerjee S, Rittenbach A, Jammes F, Tsui B and Sgouros G. Imaging, biodistribution, and dosimetry of radionuclide-labeled PDL1 antibody in an immunocompetent mouse model of breast cancer. Cancer Res. 2016; 76:472-9.

21. Bosch A, Eroles P, Zaragoza R, Vina JR and Lluch A. Triple-negative breast cancer: molecular features, 
pathogenesis, treatment and current lines of research. Cancer Treat Rev. 2010; 36:206-215.

22. Maeda H, Wu J, Sawa T, Matsumura Y and Hori K. Tumor vascular permeability and the EPR effect in macromolecular therapeutics: a review. J Control Release. 2000; 65:271284.

23. van Dam GM, Themelis G, Crane LM, Harlaar NJ, Pleijhuis RG, Kelder W, Sarantopoulos A, de Jong JS, Arts HJ, van der Zee AG, Bart J, Low PS and Ntziachristos $\mathrm{V}$. Intraoperative tumor-specific fluorescence imaging in ovarian cancer by folate receptor-alpha targeting: first inhuman results. Nat Med. 2011; 17:1315-1319.

24. Stummer W, Novotny A, Stepp H, Goetz C, Bise K and Reulen HJ. Fluorescence-guided resection of glioblastoma multiforme by using 5-aminolevulinic acid-induced porphyrins: a prospective study in 52 consecutive patients. J Neurosurg. 2000; 93:1003-1013.

25. Veiseh M, Gabikian P, Bahrami SB, Veiseh O, Zhang M, Hackman RC, Ravanpay AC, Stroud MR, Kusuma Y, Hansen SJ, Kwok D, Munoz NM, Sze RW, Grady WM, Greenberg NM, Ellenbogen RG, et al. Tumor paint: a chlorotoxin:Cy5.5 bioconjugate for intraoperative visualization of cancer foci. Cancer Res. 2007; 67:68826888.

26. Neuman BP, Eifler JB, Castanares M, Chowdhury WH, Chen Y, Mease RC, Ma R, Mukherjee A, Lupold SE, Pomper MG and Rodriguez R. Real-time, Near-Infrared Fluorescence Imaging with an Optimized Dye/Light Source/Camera Combination for Surgical Guidance of Prostate Cancer. Clin Cancer Res. 2015; 21:771-780.

27. Verbeek FP, Troyan SL, Mieog JS, Liefers GJ, Moffitt LA, Rosenberg M, Hirshfield-Bartek J, Gioux S, van de Velde CJ, Vahrmeijer AL and Frangioni JV. Near-infrared fluorescence sentinel lymph node mapping in breast cancer: a multicenter experience. Breast Cancer Res Treat. 2014; 143:333-342.

28. Vahrmeijer AL, Hutteman M, van der Vorst JR, van de Velde CJ and Frangioni JV. Image-guided cancer surgery using near-infrared fluorescence. Nat Rev Clin Oncol. 2013; 10:507-518.

29. Kennedy GT, Okusanya OT, Keating JJ, Heitjan DF, Deshpande C, Litzky LA, Albelda SM, Drebin JA, Nie S, Low PS and Singhal S. The Optical Biopsy: A Novel Technique for Rapid Intraoperative Diagnosis of Primary Pulmonary Adenocarcinomas. Ann Surg. 2015; 262:602609.

30. de Boer E, Warram JM, Tucker MD, Hartman YE, Moore LS, de Jong JS, Chung TK, Korb ML, Zinn KR, van Dam GM, Rosenthal EL and Brandwein-Gensler MS. In Vivo Fluorescence Immunohistochemistry: Localization of Fluorescently Labeled Cetuximab in Squamous Cell Carcinomas. Sci Rep. 2015; 5:10169.

31. McWilliams AM, Mayo JR, Ahn MI, MacDonald SL and Lam SC. Lung cancer screening using multi-slice thin-section computed tomography and autofluorescence bronchoscopy. J Thorac Oncol. 2006; 1:61-68.

32. Maute RL, Gordon SR, Mayer AT, McCracken MN, Natarajan A, Ring NG, Kimura R, Tsai JM, Manglik A, Kruse AC, Gambhir SS, Weissman IL and Ring AM. Engineering high-affinity PD-1 variants for optimized immunotherapy and immuno-PET imaging. Proc Natl Acad Sci U S A. 2015; 112:E6506-6514.

33. Han M and Partin AW. Current Clinical Applications of the In-capromab Pendetide Scan (ProstaScint(R) Scan, Cyt356). Rev Urol. 2001; 3:165-171.

34. Menke-van der Houven van Oordt CW, Gootjes EC, Huisman MC, Vugts DJ, Roth C, Luik AM, Mulder ER, Schuit RC, Boellaard R, Hoekstra OS, van Dongen GA and Verheul HM. 89Zr-cetuximab PET imaging in patients with advanced colorectal cancer. Oncotarget. 2015; 6:3038430393. doi: 10.18632/oncotarget.4672.

35. Turker NS, Heidari P, Kucherlapati R, Kucherlapati M and Mahmood U. An EGFR targeted PET imaging probe for the detection of colonic adenocarcinomas in the setting of colitis. Theranostics. 2014; 4:893-903.

36. Nguyen KD, Qiu Y, Cui X, Goh YP, Mwangi J, David $\mathrm{T}$, Mukundan L, Brombacher F, Locksley RM and Chawla A. Alternatively activated macrophages produce catecholamines to sustain adaptive thermogenesis. Nature. 2011; 480:104-108.

37. Lindmo T, Boven E, Cuttitta F, Fedorko J and Bunn PA, Jr. Determination of the immunoreactive fraction of radiolabeled monoclonal antibodies by linear extrapolation to binding at infinite antigen excess. J Immunol Methods. 1984; 72:77-89.

38. Lesniak WG, Sikorska E, Shallal H, Behnam Azad B, Lisok A, Pullambhatla M, Pomper MG and Nimmagadda S. Structural Characterization and in Vivo Evaluation of beta-Hairpin Peptidomimetics as Specific CXCR4 Imaging Agents. Mol Pharm. 2015; 12:941-953. 